Temizkan, M. ve Erbilen, M. (2020). 8. sınıf öğrencilerinin yazılı anlatımda planlamaya yönelik görüş ve becerilerinin değerlendirilmesi. Ana Dili Ĕgitimi Dergisi, 8(2), 469-486.

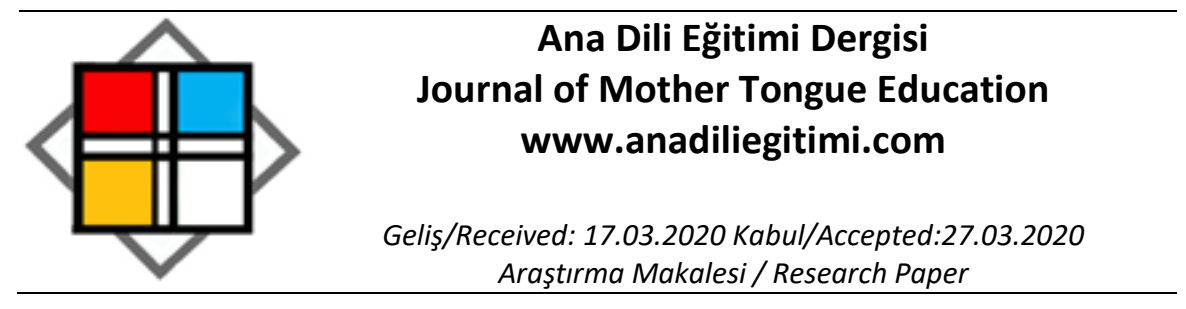

\title{
8. Sınıf Öğrencilerinin Yazılı Anlatımda Planlamaya Yönelik Görüş ve Becerilerinin Değerlendirilmesi*
}

\author{
Mehmet TEMIZKAN** \\ Metin ERBILEN ${ }^{* * *}$
}

\begin{abstract}
Öz
$\mathrm{Bu}$ araştırmanın amacı, ortaokul 8. sınıf öğrencilerinin yazılı anlatımda planlama becerilerini değerlendirmektir. Çalışma hem nicel hem de nitel değerlendirme tekniklerinin birlikte kullanıldığ betimleyici bir araştırmadır. Araştırmanın evrenini Gaziantep ili, Şahinbey ile Şehitkâmil ilçelerinde öğrenim gören 8. sınıf öğrencileri; örneklemini sosyoekonomik durumuna göre alt-orta ve üst düzeylerde bulunan 6 ortaokulun 8 . sınıflarında öğrenim gören toplam 370 öğrenci oluşturmaktadır. Araştırmada veri toplama aracı olarak "Öğrenci Görüşlerini Değerlendirme Ölçeği" ve "Yazılı Anlatımda Planlama Becerisi Çözümleyici Puanlama Anahtarı" kullanılmıştır. Araştırmada veriler başlık, konu, ana düşünce ve yardımcı düşünceler, anlatım biçimleri ve düşünceyi geliştirme yolları, giriş, gelişme, sonuç boyutları açısından ayrı ayrı incelenmiştir. Her bir boyutta "yetersiz" ve "çok yetersiz" düzeylerin toplamda \%50’nin üzerine çıtı̆̆ı saptanarak öğrencilerin, yazılı anlatımı planlamada yeterli bir başarı göstermedikleri sonucuna varılmıştır.
\end{abstract}

Anahtar Kelimeler: Türkçe Öğretimi, Yazma Becerisi, Planlama.

\section{Evaluation of Opinions And Skills of 8th Grade Students Toward Planning In Written Expression}

\begin{abstract}
The aim of this research is to evaluate the planning skills of middle school 8th grade students in written expression. This study is a descritptive work, where both quantitive and qualitive analysis methods were used. The universe of this study is consisted of Turkish Language teachers and $8^{\text {th }}$ grade students, who work/study in schools in Gaziantep City, Şahinbey and Şehitkâmil Cityquarters. Sample is consisted of $3708^{\text {th }}$ grade students from different schools. The data gathering instrument was used "Rubric of analysing planning skills in writting expression" in this study. All the data were examined separately from the aspect of title, subject, main idea and sub-ideas, expression styles and ways of developing a thought, introduction, body and conclusion. At each dimension "poor" and "very poor" levels were determined if they exceed $50 \%$ or not, and thus a conclusion was made whether the students have shown a sufficient success or not.
\end{abstract}

Key Words: Turkish Education, Writing Skills, Planning.

\section{Giriş}

Günümüzde iletişim, içinde yaşadığımız çağa adını verecek kadar önem kazanmıştır. İnsan zekâsının bir ürünü olan internet hayatın içine girmiş, zaman ve mekân kavramını ortadan kaldırmıştır. Insanların her yerde ve her an birbirleriyle iletişim içinde olma gereksinimlerini karşılama amacıyla

\footnotetext{
* Bu çalışmada Mustafa Kemal Üniversitesi Sosyal Bilimler Enstitüsünde tamamlanan Ortaokul Öğrencilerinin Yazılı Anlatımda Planlama Becerilerinin Değerlendirilmesi isimli yüksek lisans tezinin verilerinden yararlanılmıştır. ** Prof. Dr., Hatay Mustafa Kemal Üniversitesi, Eğitim Fakültesi, Türkçe ve Sosyal Bilimler Eğitimi Bölümü, Hatay, temizkanm79@gmail.com, ORCID: 0000-0001-7437-6754

*** Doktora Öğrencisi, Hatay Mustafa Kemal Üniversitesi, Sosyal Bilimler Enstitüsü, Hatay, merbilen@windowslive.com, ORCID: 0000-0002-2627-9770
} 
teknoloji, hızla kendini geliştirme ve yenileme yoluna gitmiştir. Sosyal bir varlık olan insan, teknolojinin gelişimindeki bu hızından faydalanarak daima iletişim hâlinde olup sosyal olmanın gereksinimini en hızlı şekilde sağlamaktadır. Bu iletişimin de temel malzemesi dildir, bir anlamda bu iletişim ancak dil ile gerçekleşir. Bir dili iyi ve doğru kullanmak, onun bütün özelliklerini, inceliklerini ve kullanım alanlarını bilmekle mümkündür. İletişimin sağılılı olması, kişinin aldığı dil eğitimine; bunun sonucu olarak da dili kullanma becerisine bağııdır. Dil eğitiminin amacı kişiye, okuma, yazma, konuşma ve dinleme adı verilen dört temel dil becerisini kazandırmaktır. Bu becerilerden okuma ve dinleme anlama için, konuşma ve yazma ise anlatım için gereklidir.

İnsanın önemli özelliklerinden biri düşünme ise diğeri de buna bağıı olarak anlatmadır. Hepimiz her gün bir şeyler anlatırız. Yaşadıklarımızı, gördüklerimizi, tanık olduklarımızı, isteklerimizi, duygularımızı, düşüncelerimizi, beklentilerimizi ve hayallerimizi sözlü veya yazılı olarak anlatırız. Ancak sözlü anlatımdaki dil kullanma pratiği yazılı anlatımdan farklıdır. Sözlü anlatımdaki kişi daha rahattır; ancak yazılı anlatımda rahatlığın yerini sorumluluk alır. Yazılı anlatım, dili bütün incelikleriyle güçlü bir biçimde kullanma becerisini ve belli bir birikimi gerektirir.

Yazma becerisi, insanlara bilgilerini düzenleme, zenginleştirme, düşüncelerini genişletme ve planlı biçimde ifade etme imkânı verdiği için çok önemli bir dil becerisidir. Konuşmayla birlikte bireyin kendisini ifade etme yollarından biri olan yazma, insanoğlunun binlerce yıldır kullandığı en önemli iletişim becerilerindendir. Yazma becerisini kazanmak, bireyin hem günlük ihtiyaçlarını karşılaması, eğitimini sürdürmesi, hayatında başarılı olması, anlama ve anlatma yeteneğini yükselterek insanları anlayan, seven ve insanlar tarafından anlaşılan sevilen biri olması hem de kendi öz dilinin edebi eserlerinden tat alabilmesi için gereklidir.

Yazma araştırmacılar tarafından farklı kavramlarla karşılanmıştır. Bunlar yazma, yazılı anlatım, kompozisyon gibi kavramlardır. Bu kavram çeşitliliğine rağmen yapılan tanımlar küçük farklar dışında birbirine benzer nitelik taşımaktadır. Buna göre yazılı anlatım bir fikrin, duygunun, düşüncenin anlamlı ve çekici yanlarını, dili en güzel şekilde kullanarak belli bir plan dâhilinde başkalarına ve yarınlara ulaştırmaya, böylece kalıcılığı sağlamaya imkân veren bir araçtır (Bülbül, 2000; Özkırımlı, 2002; Aktaş ve Gündüz, 2002). Gündüz'e (2003: 15) göre yazmak, gizlerin çözümlenmesidir; yaşamın özünü kavramak için çıkılan yoldur; dünyada bir şeylerin değişmesi için gösterilen çabadır. Yazmanın, kişisel olduğu kadar, meslekî bir ihtiyaç da olduğunu belirten Kantemir (1997) yalnız yazarların değil, türlü iş dallarında çalışanların da yazmak zorunda olduğu üzerinde durmuştur.

2005 İlköğretim Türkçe Dersi Öğretim Programına kadarki süreçte benimsenen davranış̧̧ı yaklaşımın yerini yapılandırmacı yaklaşımın almasıyla birlikte yazma becerisini geliştirmede geleneksel bir yaklaşım olan ürün odaklı yazma yaklaşımının yerine süreç odaklı yazma yaklaşımı benimsenmeye başlanmıştır. Süreç odaklı yazma yaklaşımı yazmayı bir ürün olarak değil, süreç olarak ele almaktadır. Diğer bir deyişle, bu yeni yaklaşım 'ne' yazıldı sorusunun yanıtı olan ürün yerine 'nasıl' yazıldı sorusunun yanıtı olan süreç üzerinde durmanın gerekliliğini vurgulayan bir yaklaşımdır (Ülper, 2008). Bu yaklaşımda ağırlık noktasını şu görüş oluşturur: Yazılı anlatım becerisinin geliştirilmesi sürecinde öğrenciler, iyi bir yazarın gerçek yazma sürecindeki yaşantılarından geçirilirlerse, kısacası ürüne ağırlık vermek yerine sürece ağırlık verilirse, ortaya çıkan ürünün niteliği de artacaktır. Öğretmen, öğrencinin bu sürecin çeşitli aşamalarındaki gelişimini gözlemlemek ve değerlendirmek durumundadır. Kısacası süreç yaklaşımı, ürünün ortaya çıkmasını sağlayan süreçlerin (öğrenme yaşantılarının) sınıf ortamına taşınmasını olanaklı kılar (White ve Arndt, 1991, akt: Çakır, 2003: 33).

Yazmada süreç yaklaşımıyla birlikte öğretmen ve öğrenci rolleri değişmektedir. Öğrencilerin yazma becerilerini geliştirmeye dayanan bu yaklaşımda öğrencilerin metin oluşturuncaya kadar geçirdikleri sürede ortaya koydukları beceriler dikkate alınmaktadır. Önemli olan metin değil metin oluşturma becerilerine sahip olmaktır. Bu sebeple değerlendirmeler sürece dayalı olarak yapılmaktadır. Öğrenci bu yaklaşımda aktif bir role sahiptir. Süreç boyunca öğrenci kısıtlamalara maruz kalmadığı için bilgiyi yansıtarak değil yapılandırarak, hayal gücünü kullanarak ve düşüncelerini açıkça ortaya koyarak metnini oluşturur (Tabak ve Göçer, 2013: 150-151). Öğretmen öğrenciye rehberlik eden, onunla süreci yaşayan kişidir. Çünkü öğretmenin öğrenciyi güdülemesi yeterli görülmemekte, öğretmen de bir öğrenci gibi bu süreci yazarak yaşamaktadır. Süreç merkezli yaklaşımda, öğretmenle öğrencinin ilişkisi 
usta çırak ilişkisini andııır, usta çırağa öğretir; ama kendisi de sanatındaki eserleri tanır ve yeni eserler yaratır (Oral, 2008: 25).

Süreç merkezli yaklaşımda yazı; düşüncenin ve dilin keşfedilmesi, yenilenip değiştirilmesi olarak görülmektedir. Bu yaklaşım, yazıyı yazmadan önce ve yazım sırasında ortaya çıkan farklı süreçlerle alt beceriler üzerinde durur ve stratejiler üretir. Bu alt süreçler, ön yazım, taslak yazma, gözden geçirip düzeltme ve paylaşmadır. Bu yaklaşımda öğretmen, öğrencinin yazım sürecinde ona rehberlik etme ve destek vermekle yükümlüdür (Maltepe, 2006: 32).

Süreç odaklı öğrenme yaklaşımında yazma becerisi bazı aşamalardan oluşan bir "süreç" olarak görülmektedir. Bu aşamalar genellikle ilgi uyandırma, planlama, yazma taslağı oluşturma, yazma, düzeltme/değerlendirme ve paylaşma/yayınlama olarak tespit edilmiştir. Bu aşamalardan biri ve öncelikli olanı planlamadır. Yazılı anlatım çalışmalarında fikirlerin özgünlüğü, farklı bir tarzda söylenmesi, duygu ve düşüncelerin anlaşılırlığı için başlangıç aşamasında metin sağlam bir şekilde planlanmalıdır. Çünkü yazııı anlatım ürünü olan metin, planlı bir anlatım göstermezse okuyucu yazıdaki duygu ve düşünceleri okurken anlamlandırmakta güçlük çeker. Eğer yazı planlanmaz ve fikirler mantıklı ve çekici bir anlatım akışı içinde verilmezse okur, yazının içinde kaybolur. Bu nedenle iyi bir yazılı anlatım ürünü, yazarın söyleyeceklerini başlangıçta planlamasına, yazma taslağı oluşturmasına, yazma durumuna göre bu taslağı düzenlemesine bağıı olarak nitelikli hâle gelir.

\section{Yazılı Anlatımda Planlama}

Yazılı anlatımda plan; plan, düşünsel düzen, tertip, düzen gibi farklı kavramlarla açıklanmaktadır. Özdemir'e (2005: 136) göre yazımızın ya da konuşmamızın içeriğini oluşturacak düşünceleri, duyguları, gözlem ve yaşantıları kalemimizin, dilimizin ucuna geldiği gibi anlatamayız. Gelişigüzel söyleyip yazamayız. Bunları aralarındaki ilgi ve önem derecelerine göre ayırıp sıralamamız gerekir. Bu sıralama işine anlatımın düşünsel düzeni (planı) denir. Plan, yazımızı yazarken bize kılavuzluk eder. Söze hangi düşünceyle başlayacağımızı, düşünceleri nasıl geliştireceğimizi, bunlar arasında nasıl geçiş ve bağlantılar sağlayacağımızı bize plan gösterir (Özdemir, 2005: 136-137). Plan, bir eserde veya yazıda neyin, nerede, ne ölçüde söyleneceğinin önceden tespit edilmesi ve bunun sıraya konulmasıdır. Plan bir yazının omurgasıdır. Plansız bir yazı karmakarışık olur (Yavuz, Yetiş ve Birinci, 1998: 304).

Plan, zihinde meydana gelen fikirlere düzen vermek, gereksiz ayrıntıları temizlemek amacıyla yapılır. Birçok düşünce zihinde bir anda uyanmaz, yer yer fikirler canlanır bu yüzden düzen olmaz ve fikirlerin tesirli olması beklenemez. Bir düzen sağlamak amacıyla konuyla ilgili zihne gelen düşünceler önce gelişigüzel not edilir, sonra da neyin, nerede yer alacağına karar verilir. Plan, yazıya başlamadan önce tasarlanır ve yazının gelişme seyrine göre plana eklemeler veya plandan çıkartmalar yapılır. Daha sonra yazı temize çekilir. Bu tasarıdan sonra ana düşünce belirlenip düşünceler düzene sokulur (Babacan, 2007: 45; Ağca, 2006: 111-113).

Plansız bir yazı veya eserde söylenmek istenenlerin yeri ve sırası önceden belirlenmediği için fikir karmaşık olur. En önemli noktalar gözden kaçırılabilir. Yazının başı ortası ve sonu arasında kopukluklar hatta zıtlıklar ortaya çıkabilir. Bazı hususlar çok belirtildiği hâlde, bazı hususlar kapalı ve işlenmemiş olabilir. Plansız bir bina yapılamayacağı gibi plansız bir eser veya yazı da olmaz. Önceden yapılan bir planla fikir, anlatılmak istenen belirli bir sıra ve ölçüde muntazam bir şekilde gelişir. Bunun için başarılı bir kompozisyonda plan son derece önemlidir (Yavuz vd.,1998: 305).

Herhangi bir metni okuduktan sonra "Kafam karıştı, hiçbir şey anlayamadım.", hatta "Okuduğuma değmedi." şeklinde düşüncelere kapılıyorsak; bu, metnin iyi bir plan yapılmadan kaleme alındığını gösterir. Bununla beraber, başka unsurların da bizi böyle düşüncelere sevk etmesi söz konusudur; ancak bir metnin amacına ulaşmasında planlamanın çok önemli bir yeri olduğu unutulmamalıdır. Yazıda planın yapılması, anlatılanların düzenli olmasını, daha da önemlisi, verilmek istenen mesajın etkili bir şekilde ortaya konmasını sağlar. Böylece yazı, bir bütünlük arz ederek, düşünceleri yeterli ve doğru olarak okuyucuya aktaracaktır (Yaman ve Köstekçi, 1998: 132).

Yazıya başlamadan bir planın hazırlanması, konu ile ilgili düşüncelerin düzenli ve etkili bir şekilde açıklanmasını sağlar. Böylece yazıda birlik ve bütünlük ilkeleri gerçekleşmiş, duygu ve düşünceler etkili 
bir şekilde ifade imkânı bulmuş olur. Böyle bir planı gerçekleştirmiş kişi için artık yazmak, zihindeki bilgi ağacının meyvesini toplamak kadar zevkli ve kolay bir iş olacaktır (Paçacıoğlu, 174).

Plan yazıyı dağınıklıktan kurtarır; yazılanlara anlaşıı, inandırıcı ve etkileyici olma nitelikleri kazandııır. Böylece yazıda düşünce birliği sağlanmış olur. Böyle bir yazıyı okuyan kişi yavaş yavaş konunun içine girecek ve yazanın düşüncelerini kavrayarak yazıda verilmek istenilenler doğrultusunda düşünecektir (Bayramıçlılar, Tosun ve Ak, 1990: 11).

Kantemir (1997: 140-141) yazııı anlatımda planlamanın yararlarını şu şekilde sıralar:

a) Yazıyı, doldurma ve boş sözlerden ve bizi, konu dışına çıkmaktan kurtarır.

b) Yazarken, fikirleri rahatça anlatmayı ve yazının kolay anlaşılmasını sağlar,

c) Düşünce, duygu ve hayallerimizi, ölçülü biçimde anlatmaya yarar,

d) Düzenli yazacak kişiyi, kararsızlık ve zaman kaybından kurtarır,

e) Konuda birliği kurar,

f) Duygu, hayal ve fikirler, en uygun sözcük ve deyimlerle anlatılır.

Konu ve ana fikirle ilgili bilgiler okuma, araştırma ve yaşantılardan elde edilir. Fakat yazıya başlarken hangi fikrin seçileceği, fikirlerin nasıl geliştirileceği, nasıl sonuçlandırılacağı planla ilgilidir. Bu çalışmayla yazılı anlatımda hedeflenen kazanımlara ulaşmada önemli bir süreç olan, yararları kısaca yukarıda sıralanan planlama konusuna dikkat çekilmektedir. Buna göre araştırmanın problem cümlesi “8. sınıf öğrencilerinin yazııı anlatım çalışmalarını planlayabilme becerileri hangi düzeydedir?” şeklinde ifade edilebilir.

\section{Yöntem}

Bu bölümde araştırmanın modeli, evren ve örneklemi, veri toplama araçları, verilerin analizi gibi başlıklarda bilgiler verilmektedir.

\section{Araştırmanın Modeli}

8. sınıf öğrencilerinin yazıı anlatımda planlama becerilerini değerlendirme amacıyla gerçekleştirilen bu araştırma, genel tarama modelindedir. Tarama modelleri, geçmişte ya da hâlen var olan bir durumu var olduğu şekliyle betimlemeyi amaçlayan araştırma modelleridir. Tarama modelleri iki şekilde sınıflandırılabilir. Bunlar, genel tarama modelleri ile örnek olay taramalarıdır. Genel tarama modelleri, çok sayıda elemandan oluşan evren hakkında genel bir yargıya varmak amacı ile evrenin tümü ya da ondan alınan bir grup, örnek ya da örneklem üzerinde yapılan tarama modelidir (Karasar, 2009: 77-79). Bu özelliğinden dolayı bu araştırma genel tarama modelinde gerçekleştirilmiştir.

\section{Örneklem}

Araştırmanın evrenini Gaziantep ili Şahinbey ve Şehitkâmil ilçelerinde yer alan ilköğretim okullarının 8. sınıf öğrencileri oluşturmaktadır. Evrende yer alan öğrencilerin hepsine ulaşmak mümkün olmayacağı için örneklem alma yoluna gidilmiştir. Tabakalı örneklem alma yoluyla Gaziantep merkez ilçelerindeki farkı sosyoekonomik düzeylere ait ortaokullardan 370 sekizinci sınıf öğrencisi örneklem olarak belirlenmiştir.

\section{Veri Toplama Araçları}

Araştırma süresince veri toplamak amacıyla "Öğrenci Görüşlerini Değerlendirme Ölçeği” ve "Yazııı Anlatımda Planlama Becerisi Çözümleyici Puanlama Anahtarı" kullanılmıştır. Yazılı anlatımda planlama becerisine yönelik öğrenci görüşlerini değerlendirmek üzere "Öğrenci Görüşlerini Değerlendirme Ölçeği" geliştirilmiştir. Bu ölçek geliştirilirken öncelikle yazılı anlatım becerisinde planlamanın ilgili olabileceği boyutlar ortaya koyulmuştur. Bu boyutlar "başılı, konu, ana düşünce ve yardımcı düşünceler, anlatım biçimleri, düşünceyi geliştirme yolları, giriş, gelişme, sonuç" olmak üzere toplam sekiz tanedir. Bunlardan başlık boyutunda 8 , konu boyutunda 6 , ana düşünce ve yardımcı düşünceler boyutunda 6 , anlatım biçimleri boyutunda 2 , düşünceyi geliştirme boyutunda 7 , giriş boyutunda 4 , gelişme boyutunda 7 , sonuç boyutunda 6 olmak üzere toplam 46 madde bulunmaktadır. Maddeler "hiçbir zaman, bazen, her zaman" olmak üzere üçlü likert şeklinde derecelendirilmiştir. Öğrenci Görüşleri Değerlendirme Ölçeğinin geçerliliğini sağlamak amacıyla Türkçe Eğitimi alanında 
uzman 5 öğretim üyesinin görüşleri alınmış ve öneriler doğrultusunda ölçek kullanıma hazır hâle getirilmiştir.

Araştırmada ayrıca veri toplama aracı olarak 8. sınıf öğrencilerinin yazılı anlatım çalışmalarında planlama becerilerinin hangi düzeyde olduğunu tespit etmek amacıyla "Yazılı Anlatımda Planlama Becerisi Çözümleyici Puanlama Anahtarı" kullanılmıştır. Dereceli puanlama anahtarı (rubric) niteliğindeki bu veri toplama aracı toplam 7 boyuttan (başlık, konu, ana ve yardımcı düşünceler, anlatım biçimleri ve düşünceyi geliştirme yolları, giriş, gelişme, sonuç) ve 5 derecelendirme aralığından (çok iyi, iyi, orta, yetersiz, çok yetersiz) oluşmaktadır. Dolayısıyla öğrenciler en az 7, en fazla 35 puan alabilmektedirler. Dereceli puanlama anahtarının geçerliliği için uzman görüşüne başvurulmuştur. Güvenilirliğin sağlanması için de değerlendiriciler arasındaki uyuma başvurulmuş ve bütün boyutlar için güvenilirlik katsayısı .81 olarak tespit edilmiştir.

\section{Verilerin Toplanması}

Araştırmada veri toplamak amacıyla öncelikle 8. sınıf öğrencilerine yazılı anlatım çalışması yaptırabilmek için yazma konularına ihtiyaç duyulmuştur. Bu yazma konuları alanlarında uzman olan 4 öğretim üyesinin toplam 8 konuya 8 . sınıf öğrencilerine uygunluk açısından vermiş oldukları puanların hesaplanmasından sonra karar verilmiştir. Bu puanlama sonrasında öğrencilere yazdırılması için belirlenen konular aşağıdaki gibidir:

1. Dost dediğiniz kişilerde aradığınız özellikleri anlatan bir kompozisyon yazınız.

2. İcat ve buluşların insan hayatına getirdiklerini anlatan bir kompozisyon yazınız.

3. İnsan hayatında ailenin ve aile ortamının önemini anlatan bir kompozisyon yazınız.

Uzman görüşü sonrasında belirlenen bu konular öğrencilere yazmaları için verilmiş ve öğrencilerden bu konulardan istedikleri herhangi birinde yazılı bir metin üretmeleri istenmiştir. Aynı zamanda öğrencilerin yazılı anlatım çalışmalarını planlama konusundaki görüşlerini belirlemek amacıyla geliştirilen "Öğrenci Değerlendirme Ölçeği” de dağıtılarak ölçeğin gerekli şekilde işaretlenmesi sağlanmıştır. İlgili konularda üretilen yazılı metinler ve işaretlenen öğrenci değerlendirme ölçeği toplandıktan sonra veri seti oluşturulmaya başlanmıştır.

\section{Verilerin Analizi}

Araştırmada elde edilen veriler iki veri toplama aracı doğrultusunda değerlendirilmiştir. Yazılı anlatım becerisi bağlamında öğrencilerin uygulamadaki görüşlerini belirlemek amacıyla veriler istatistik programıyla çözümlenmiştir. Bu verilerin analizinde frekans, yüzde, aritmetik ortalama, standart sapma gibi betimsel istatistik teknikleri kullanılmıştır. Öğrencilerin yazılı anlatımda planlamaya ilişkin becerilerini değerlendirmek amacıyla dereceli puanlama anahtarına verilen yanıtlar çözümlenmiş ve bunlar üzerinde yüzde, frekans analizleri yapılmıştır.

\section{Bulgular}

Bu bölümde araştırmada elde edilen bulgular verilmektedir. Bu amaçla öncelikle öğrencilerin planlamada uygulamaya ilişkin görüşlerine daha sonra dereceli puanlama anahtarından elde edilen bulgulara yer verilmektedir.

\section{Öğrencilerin Yazılı Anlatım Çalışmalarını Planlamadaki Uygulamalarına ilişkin Görüşleri Öğrencilerin Başlık Boyutuna ilişkin Görüşleri}

Öğrencilerin başık boyutuna ilişkin görüşleri aşağıdaki tabloda verilmektedir.

Tablo 1

Öğrencilerin Başık Boyutuna illişkin Görüşleri

\begin{tabular}{lllllllll}
\hline BAŞLIK & \multicolumn{2}{c}{$\begin{array}{c}\text { Hiçbir } \\
\text { Zaman }\end{array}$} & \multicolumn{2}{c}{ Bazen } & \multicolumn{2}{c}{$\begin{array}{c}\text { Her } \\
\text { Zaman }\end{array}$} & TOPLAM \\
\hline \multirow{3}{*}{ M1 } & $\mathrm{f}$ & $\%$ & $\mathrm{f}$ & $\%$ & $\mathrm{f}$ & $\%$ & $\mathrm{f}$ & $\%$ \\
\cline { 2 - 9 } & 5 & 1,4 & 41 & 11,1 & 324 & 87,6 & 370 & 100,0
\end{tabular}




\begin{tabular}{lllllllll} 
M2 & 47 & 12,7 & 134 & 36,2 & 189 & 51,1 & 370 & 100,0 \\
M3 & 2 & 0,5 & 85 & 23,0 & 283 & 76,5 & 370 & 100,0 \\
M4 & 10 & 2,7 & 134 & 36,2 & 226 & 61,1 & 370 & 100,0 \\
M5 & 12 & 3,2 & 151 & 40,8 & 207 & 55,9 & 370 & 100,0 \\
M6 & 21 & 5,7 & 145 & 39,2 & 204 & 55,1 & 370 & 100,0 \\
M7 & 7 & 1,9 & 141 & 38,1 & 222 & 60,0 & 370 & 100,0 \\
M8 & 14 & 3,8 & 117 & 31,6 & 239 & 64,6 & 370 & 100,0 \\
\hline
\end{tabular}

Tablo 1'e göre öğrencilerin \% 87,6'sı yazdığı metnin bir başlığının bulunmasına dikkat ettiğini; \% 51,1'i başlığı metni yazıp bitirdikten sonra seçtiğini; \% 76,5'i başlığın metnin konusu hakkında bilgi vermesine dikkat ettiğini; \% 61,1'i seçtiği başlığın okuyucunun dikkatini çekmesine önem verdiğini; $\% 55,9^{\prime}$ u seçtiği başlığın kısa ve öz olmasına dikkat ettiğini; \% 55,1'i seçtiği başlı̆ın orijinal (farklı, kendime özgü) olmasına dikkat ettiğini; \% 60,0'ı seçtiği başlığın metinde anlattıklarını tam olarak kapsayacak nitelikte olmasına dikkat ettiğini; \% 64,6'sı seçtiği başlığın metnin ana düşüncesine uygun olmasına dikkat ettiğini belirtmiştir.

Öğrencilerin Konu Boyutuna ilişskin Görüşleri

Öğrencilerin konu boyutuna ilişkin görüşleri aşağıdaki tabloda verilmektedir.

Tablo 2

Öğrencilerin Konu Boyutuna iliş̧kin Görüşleri

\begin{tabular}{lllllllll}
\hline KONU & \multicolumn{3}{c}{$\begin{array}{c}\text { Hiçbir } \\
\text { Zaman }\end{array}$} & \multicolumn{2}{c}{ Bazen } & \multicolumn{2}{c}{$\begin{array}{c}\text { Her } \\
\text { Zaman }\end{array}$} & \multicolumn{2}{c}{ TOPLAM } \\
\hline & $\mathrm{f}$ & $\%$ & $\mathrm{f}$ & $\%$ & $\mathrm{f}$ & $\%$ & $\mathrm{f}$ & $\%$ \\
\cline { 2 - 10 } M9 & 36 & 9,7 & 162 & 43,8 & 172 & 46,5 & 370 & 100,0 \\
M10 & 17 & 4,6 & 119 & 32,2 & 234 & 63,2 & 370 & 100,0 \\
M11 & 30 & 8,1 & 164 & 44,3 & 176 & 47,6 & 370 & 100,0 \\
M12 & 29 & 7,8 & 167 & 45,1 & 174 & 47,0 & 370 & 100,0 \\
M13 & 6 & 1,6 & 87 & 23,5 & 277 & 74,9 & 370 & 100,0 \\
M14 & 14 & 3,8 & 145 & 39,2 & 211 & 57,0 & 370 & 100,0 \\
\hline
\end{tabular}

Tablo 2'ye göre öğrencilerin \% 46,5'i yazmaya başlamadan önce konuyu sınırlandırdığını ve konunun ana düşüncesini belirlediğini; \% 63,2'si yazmaya başlamadan önce konu ile ilgili aklındaki bütün düşünceleri sıraladığını; \% 47,6'sı yazmak için sıraladığı düşünceler arasından ana düşünceyi destekleyecek olanları ayıkladığını; \% 47'si yazmak için ayıkladığı düşünceleri uygun başlıklar altında gruplandırdığını; \% 74,9'u okuyucunun, yazdığı metnin konusunu kolayca anlayabilmesine dikkat ettiğini; \% 57'si yazdığı metinde konunun anlaşılmasını sağlayacak anahtar kelimeler kullanmaya dikkat ettiğini belirtmiştir.

\section{Öğrencilerin Ana Düşünce ve Yardımcı Düşünceler Boyutuna ilişskin Görüşleri}

Öğrencilerin ana düşünce ve yardımcı düşünceler boyutuna ilişkin görüşleri aşağıdaki tabloda verilmektedir.

Tablo 3

Öğrencilerin Ana Düşünce ve Yardımcı Düşünceler Boyutuna ilişkin Görüşleri

\begin{tabular}{lllllllll}
$\begin{array}{l}\text { ANA DÜŞÜNCE VE } \\
\text { YARDIMCI DÜŞÜNCELER }\end{array}$ & $\begin{array}{l}\text { Hiçbir } \\
\text { Zaman }\end{array}$ & Bazen & & $\begin{array}{l}\text { Her } \\
\text { Zaman }\end{array}$ & TOPLAM \\
\hline & $\mathrm{f}$ & $\%$ & $\mathrm{f}$ & $\%$ & $\mathrm{f}$ & $\%$ & $\mathrm{f}$ & $\%$ \\
\hline
\end{tabular}




\begin{tabular}{lllllllll}
\hline M15 & 16 & 4,3 & 85 & 23,0 & 269 & 72,7 & 370 & 100,0 \\
M16 & 9 & 2,4 & 140 & 37,8 & 221 & 59,7 & 370 & 100,0 \\
M17 & 14 & 3,8 & 143 & 38,6 & 213 & 57,6 & 370 & 100,0 \\
M18 & 15 & 4,1 & 153 & 41,4 & 202 & 54,6 & 370 & 100,0 \\
M19 & 9 & 2,4 & 150 & 40,5 & 211 & 57,0 & 370 & 100,0 \\
M20 & 12 & 3,2 & 106 & 28,6 & 252 & 68,1 & 370 & 100,0 \\
\hline
\end{tabular}

Tablo 3'e göre öğrencilerin \% 72,7'si yazdığı metnin bir ana düşüncesi olmasına dikkat ettiğini; \% 59,7'si yazdığı metnin ana düşüncesinin belirgin, açık bir biçimde ortaya konulmasına dikkat ettiğini; \% 57,6'sı yazdığı metinde ortaya koyulan ana düşüncenin metnin genelini içermesine dikkat ettiğini; \% 54,6 'sı metinde ele alınan ana düşünceyi destekleyecek yardımcı düşüncelerin bulunmasına dikkat ettiğini; \% 57'si yazdığı metinde yardımcı düşüncelerin açık, belirgin bir biçimde bulunmasına dikkat ettiğini; \% 68,1'i metindeki yardımcı düşünceler arasında mantıklı bağlantılar kurmaya dikkat ettiğini belirtmiştir.

\section{Öğrencilerin Anlatım Biçimi Boyutuna ilişkin Görüşleri}

Öğrencilerin anlatım biçimi boyutuna ilişkin görüşleri aşağıdaki tabloda verilmektedir.

Tablo 4

Öğrencilerin Anlatım Biçimi Boyutuna Iliş̧kin Görüşleri

\begin{tabular}{lcccccccc}
\hline ANLATIM BiçiMi & \multicolumn{2}{c}{$\begin{array}{c}\text { Hiçbir } \\
\text { Zaman }\end{array}$} & \multicolumn{2}{c}{ Bazen } & \multicolumn{2}{c}{$\begin{array}{c}\text { Her } \\
\text { Zaman }\end{array}$} & \multicolumn{2}{c}{ TOPLAM } \\
\hline & $\mathrm{f}$ & $\%$ & $\mathrm{f}$ & $\%$ & $\mathrm{f}$ & $\%$ & $\mathrm{f}$ & $\%$ \\
M21 & 11 & 3,0 & 97 & 26,2 & 262 & 70,8 & 370 & 100,0 \\
M22 & 8 & 2,2 & 122 & 33,0 & 240 & 64,9 & 370 & 100,0 \\
\hline
\end{tabular}

Tablo 4'e göre öğrencilerin \% 70,8'i metinde ele alınan konuya uygun anlatım biçimlerini kullanmaya dikkat ettiğini; \% 64,9'u kullandığı anlatım biçimlerinin metnin yazıış amaçlarına uygun olmasına dikkat ettiğini belirtmiştir.

\section{Öğrencilerin Düşünceyi Geliştirme Yolları Boyutuna ilişkin Görüşleri}

Öğrencilerin düşünceyi geliştirme boyutuna ilişkin görüşleri aşağıdaki tabloda verilmektedir.

Tablo 5

Öğrencilerin Düşünceyi Geliştirme Boyutuna iliş̧kin Görüşleri

\begin{tabular}{lllllllll}
\hline $\begin{array}{l}\text { DÜš̈̈nCEYi } \\
\text { GELişTiRME YOLLARI }\end{array}$ & \multicolumn{3}{c}{$\begin{array}{c}\text { Hiçbir } \\
\text { Zaman }\end{array}$} & \multicolumn{2}{c}{ Bazen } & \multicolumn{2}{c}{$\begin{array}{c}\text { Her } \\
\text { Zaman }\end{array}$} & \multirow{2}{*}{ TOPLAM } \\
\hline \multirow{3}{*}{ M23 } & $\mathrm{f}$ & $\%$ & $\mathrm{f}$ & $\%$ & $\mathrm{f}$ & $\%$ & $\mathrm{f}$ & $\%$ \\
\cline { 2 - 11 } M24 & 11 & 3,0 & 137 & 37,0 & 222 & 60,0 & 370 & 100,0 \\
M25 & 13 & 3,5 & 136 & 36,8 & 221 & 59,7 & 370 & 100,0 \\
M26 & 12 & 3,2 & 182 & 49,2 & 176 & 47,6 & 370 & 100,0 \\
M27 & 33 & 8,9 & 194 & 52,4 & 143 & 38,6 & 370 & 100,0 \\
M28 & 31 & 8,4 & 140 & 37,8 & 199 & 53,8 & 370 & 100,0 \\
M29 & 34 & 9,2 & 174 & 47,0 & 162 & 43,8 & 370 & 100,0 \\
\hline
\end{tabular}

Tablo 5'e göre öğrencilerin \% 60'ı metinde ele alınan konuyu zenginleştirmek amacıyla düşünceyi geliştirme yollarından yararlandığııı; \% 59,7'si metinde ele aldığı kavramları tanımladığını; \% 47,6'sı yazıda ele aldığı düşünceleri verdiği örneklerle somutlaştırdığını; \% 38,6'sı metinde tanınmış kişilerin düşünce ve sözlerine yer verdiğini; \% 53,8'i metinde düşünceleri karşılaştırarak ortaya 
koyduğunu; \% 43,8'i metinde ele aldığı soyut ifadeleri benzetme yaparak somutlaştırdığını; \% 37,8'i metinde ele aldığı düşünceleri kanıtlama amacıyla sayısal verilerden yararlandığını belirtmiştir.

\section{Öğrencilerin Giriş Boyutuna ilişkin Görüşleri}

Öğrencilerin giriş boyutuna ilişkin görüşleri aşağıdaki tabloda verilmektedir.

Tablo 6

Öğrencilerin Giriş Boyutuna iliş̧kin Görüşleri

\begin{tabular}{llcccccccc}
\hline GiRiş & \multicolumn{3}{c}{$\begin{array}{c}\text { Hiçbir } \\
\text { Zaman }\end{array}$} & \multicolumn{2}{c}{ Bazen } & \multicolumn{2}{c}{$\begin{array}{c}\text { Her } \\
\text { Zaman }\end{array}$} & \multicolumn{2}{c}{ TOPLAM } \\
\hline & $\mathrm{f}$ & $\%$ & $\mathrm{f}$ & $\%$ & $\mathrm{f}$ & $\%$ & $\mathrm{f}$ & $\%$ \\
\cline { 2 - 11 } M30 & 8 & 2,2 & 65 & 17,6 & 297 & 80,3 & 370 & 100,0 \\
M31 & 16 & 4,3 & 101 & 27,3 & 253 & 68,4 & 370 & 100,0 \\
M32 & 14 & 3,8 & 122 & 33,0 & 234 & 63,2 & 370 & 100,0 \\
M33 & 26 & 7,0 & 131 & 35,5 & 213 & 57,6 & 370 & 100,0 \\
\hline
\end{tabular}

Tablo 6'ya göre öğrencilerin \% 80,3'ü metinde giriş paragrafı olmasına dikkat ettiğini; \% 68,4'ü metnin giriş bölümünde konu ile ilgili temel kavramları ortaya koyduğunu; $\% 63,2$ 'si giriş bölümünün metnin bütününe ilişkin fikir verecek şekilde olmasına dikkat ettiğini; \% 57,6'sı konuya göre metne farklı giriş yapma yollarından yararlandığını belirtmiştir.

\section{Öğrencilerin Gelişme Boyutuna ilişskin Görüşleri}

Öğrencilerin geliş̧me boyutuna ilişkin görüşleri aşağıdaki tabloda verilmektedir.

Tablo 7

Öğrencilerin Gelişme Boyutuna ilişskin Görüşleri

\begin{tabular}{lcccccccc}
\hline \multirow{2}{*}{ GELişME } & \multicolumn{2}{c}{$\begin{array}{c}\text { Hiçbir } \\
\text { Zaman }\end{array}$} & \multicolumn{2}{c}{ Bazen } & \multicolumn{2}{c}{$\begin{array}{c}\text { Her } \\
\text { Zaman }\end{array}$} & \multicolumn{2}{c}{ TOPLAM } \\
\hline & $\mathrm{f}$ & $\%$ & $\mathrm{f}$ & $\%$ & $\mathrm{f}$ & $\%$ & $\mathrm{f}$ & $\%$ \\
M34 & 13 & 3,5 & 81 & 21,9 & 276 & 74,6 & 370 & 100,0 \\
M35 & 10 & 2,7 & 132 & 35,7 & 228 & 61,6 & 370 & 100,0 \\
M36 & 16 & 4,3 & 130 & 35,1 & 224 & 60,5 & 370 & 100,0 \\
M37 & 20 & 5,4 & 141 & 38,1 & 209 & 56,5 & 370 & 100,0 \\
M38 & 33 & 8,9 & 166 & 44,9 & 171 & 46,2 & 370 & 100,0 \\
M39 & 8 & 2,2 & 107 & 28,9 & 255 & 68,9 & 370 & 100,0 \\
M40 & 4 & 1,1 & 106 & 28,6 & 260 & 70,3 & 370 & 100,0 \\
\hline
\end{tabular}

Tablo 7'ye göre öğrencilerin \% 74,6'sı metinde gelişme bölümünün olmasına dikkat ettiğini; \% 61,6 'sı gelişme bölümünde metinde ele alınan konunun bütün ayrıntılarıyla anlatılmasına dikkat ettiğini; \% 60,5'i gelişme bölümünde düşüncelerini belli bir sıraya göre anlattığını; \% 56,5'i gelişme bölümünde anlattığı düşünceler arasında tekrara düşmekten kaçındığını; \% 46,2'si gelişme bölümünde konuyu zenginleştirmek için yerine göre deyim, atasözü ve özdeyiş kullandığını; \% 68,9'u gelişme bölümünde bilgi yanlışı yapmamaya dikkat ettiğini; \% 70,3'ü gelişme bölümünde metnin amacını açıkça ortaya koyduğunu belirtmiştir. 
Öğrencilerin Sonuç Boyutuna ilişkin Görüşleri

Öğrencilerin sonuç boyutuna ilişkin görüşleri aşă̆ıdaki tabloda verilmektedir.

Tablo 8

Öğrencilerin Sonuç Boyutuna iliş̧kin Görüşleri

\begin{tabular}{lllllllll}
\hline SONUÇ & \multicolumn{3}{c}{$\begin{array}{c}\text { Hiçbir } \\
\text { Zaman }\end{array}$} & \multicolumn{2}{c}{ Bazen } & \multicolumn{2}{c}{$\begin{array}{c}\text { Her } \\
\text { Zaman }\end{array}$} & \multicolumn{2}{c}{ TOPLAM } \\
\hline & $\mathrm{f}$ & $\%$ & $\mathrm{f}$ & $\%$ & $\mathrm{f}$ & $\%$ & $\mathrm{f}$ & $\%$ \\
\cline { 2 - 11 } M41 & 10 & 2,7 & 64 & 17,3 & 296 & 80,0 & 370 & 100,0 \\
M42 & 6 & 1,6 & 103 & 27,8 & 261 & 70,5 & 370 & 100,0 \\
M43 & 13 & 3,5 & 125 & 33,8 & 232 & 62,7 & 370 & 100,0 \\
M44 & 25 & 6,8 & 147 & 39,7 & 198 & 53,5 & 370 & 100,0 \\
M45 & 12 & 3,2 & 123 & 33,2 & 235 & 63,5 & 370 & 100,0 \\
M46 & 25 & 6,8 & 104 & 28,1 & 241 & 65,1 & 370 & 100,0 \\
\hline
\end{tabular}

Tablo 8'e göre öğrencilerin \% 80'i metinde bir sonuç bölümü olmasına dikkat ettiğini; \% 70,5'i sonuç bölümünde konuyu etkili bir biçimde bitirdiğini; \% 62,7'si sonuç bölümünde metnin ana düşüncesini özetleyecek ifadelere yer verdiğini; \% 53,5'i sonuç bölümünde okuyucunun zihninde oluşabilecek sorulara cevap verdiğini; \% 63,5'i sonuç bölümünde metnin genelinde anlattıklarını özetlediğini; \% 65,1'i sonuç bölümünde anlattıklarının metnin tamamında anlattıklarıyla çelişmemesine dikkat ettiğini belirtmiştir.

Yazılı Anlatımda Planlama Becerisi Çözümleyici Puanlama Anahtarının Boyutlarına illişkin Bulgular Yazılı Anlatımda Planlama Becerisi Çözümleyici Puanlama Anahtarının Başlık Boyutuna ilişkin Bulgular

Yazılı anlatımda planlama becerisi çözümleyici puanlama anahtarının başlık boyutuna ilişkin veriler aşağıdaki tabloda verilmiştir.

Tablo 9

Çözümleyici Puanlama Anahtarının Başlık Boyutuna ilişskin Frekans ve Yüzde Değerleri

\begin{tabular}{|c|c|c|c|c|c|c|c|c|c|c|c|c|}
\hline \multirow[t]{2}{*}{ Madde } & \multicolumn{12}{|c|}{ Derecelendirme } \\
\hline & & 'etersiz & & ersiz & & ta & & İyi & & k İyi & & -AM \\
\hline \multirow{2}{*}{ Başlık } & $\mathrm{F}$ & $\%$ & $f$ & $\%$ & $\mathrm{~F}$ & $\%$ & $f$ & $\%$ & $\mathrm{f}$ & $\%$ & $f$ & $\%$ \\
\hline & 51 & 13,8 & 82 & 22,2 & 175 & 47,3 & 58 & 15,7 & 4 & 1,1 & 370 & 100 \\
\hline
\end{tabular}

Tablo 9'a göre yazılı anlatımda planlama becerisi çözümleyici puanlama anahtarının başlık boyutunda öğrencilerin \% 13,8'i çok yetersiz, \% 22,2'si yetersiz, \% 47,3'ü orta, \% 15,7'si iyi ve \% 1,1'i çok iyi düzeyindedir.

Yazılı Anlatımda Planlama Becerisi Çözümleyici Puanlama Anahtarının Konu Boyutuna ilişkin Bulgular

Yazılı anlatımda planlama becerisi çözümleyici puanlama anahtarının konu boyutuna ilişkin veriler aşağıdaki tabloda verilmiştir.

Tablo 10

Çözümleyici Puanlama Anahtarının Konu Boyutuna Illişkin Frekans ve Yüzde Değerleri

Madde Derecelendirme

$\begin{array}{llllll}\text { Konu Çok Yetersiz } & \text { Yetersiz } & \text { Orta } & \text { İyi } & \text { Çok İyi } & \text { TOPLAM }\end{array}$




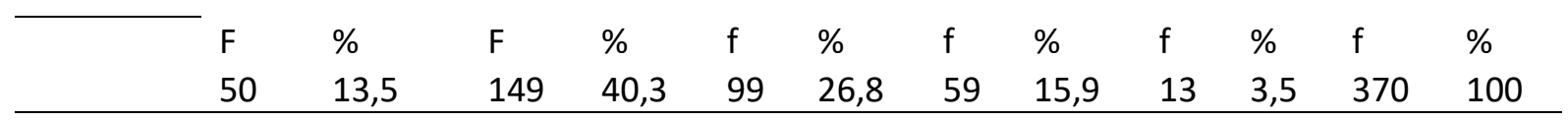

Tablo 10'a göre çözümleyici puanlama anahtarının konu boyutunda öğrencilerin \% 13,5'i çok yetersiz, \% 40,3'ü yetersiz, \% 26,8'i orta, \% 15,9’u iyi ve \% 3,5'i çok iyi düzeyindedir.

\section{Çözümleyici Puanlama Anahtarının Ana Düşünce ve Yardımcı Düşünceler Boyutuna ilişkin Bulgular}

Yazılı anlatımda planlama becerisi çözümleyici puanlama anahtarının ana düşünce ve yardımcı düşünceler boyutuna ilişkin veriler aşağıdaki tabloda verilmiştir.

Tablo 11

Çözümleyici Puanlama Anahtarının Ana Düşünce ve Yardımcı Düşünceler Boyutuna Iliş̧kin Frekans ve Yüzde Değerleri

\begin{tabular}{|c|c|c|c|c|c|c|c|c|c|c|c|c|}
\hline \multirow{3}{*}{$\begin{array}{l}\text { Ana Düşünce ve Yardımcı } \\
\text { Düşünceler }\end{array}$} & \multicolumn{12}{|c|}{ Derecelendirme } \\
\hline & \multicolumn{2}{|c|}{$\begin{array}{c}\text { Çok } \\
\text { Yetersiz }\end{array}$} & \multicolumn{2}{|c|}{ Yetersiz } & \multicolumn{2}{|c|}{ Orta } & \multicolumn{2}{|c|}{ İyi } & \multicolumn{2}{|c|}{ Çok İyi } & \multicolumn{2}{|c|}{ TOPLAM } \\
\hline & $\mathrm{F}$ & $\%$ & $f$ & $\%$ & $f$ & $\%$ & $f$ & $\%$ & $f$ & $\%$ & f & $\%$ \\
\hline & 50 & 13,5 & 164 & 44,3 & 95 & 25,7 & 51 & 13,8 & 10 & 2,7 & 370 & 100 \\
\hline
\end{tabular}

Tablo 11'e göre çözümleyici puanlama anahtarının ana düşünce ve yardımcı düşünceler boyutunda öğrencilerin \% 13,5'i çok yetersiz, \% 44,3'ü yetersiz, \% 25,7'si orta, \% 13,8'i iyi ve \% 2,7'si çok iyi düzeyindedir.

\section{Çözümleyici Puanlama Anahtarının Anlatım Biçimleri ve Düşünceyi Geliştirme Yolları Boyutuna ilişkin Bulgular}

Yazılı anlatımda planlama becerisi çözümleyici puanlama anahtarının anlatım biçimleri ve düşünceyi geliştirme yolları boyutuna ilişkin veriler aşağıdaki tabloda verilmiştir.

Tablo 12

Çözümleyici Puanlama Anahtarının Anlatım Biçimleri ve Düşünceyi Geliştirme Yolları Boyutuna iliş̧kin Frekans ve Yüzde Değerleri

\begin{tabular}{|c|c|c|c|c|c|c|c|c|c|c|c|c|}
\hline Madde & & & & & $\mathrm{De}$ & eceler & dirm & & & & & \\
\hline & & ok & Yet & ersiz & & rta & & İyi & & k İyi & TOP & AM \\
\hline Anlatım Biçimleri ve & & ersiz & & & & & & & & & & \\
\hline Düşünceyi Geliştirme Yolları & $\mathrm{F}$ & $\%$ & $f$ & $\%$ & $f$ & $\%$ & $f$ & $\%$ & $f$ & $\%$ & $f$ & $\%$ \\
\hline & 58 & 15,7 & 177 & 47,8 & 80 & 21,6 & 48 & 13,0 & 7 & 1,9 & 370 & 100 \\
\hline
\end{tabular}

Tablo 12'ye göre çözümleyici puanlama anahtarının anlatım biçimleri ve düşünceyi geliştirme yolları boyutunda öğrencilerin \% 15,7'si çok yetersiz, \% 47,8'i yetersiz, \% 21,6'sı orta, \% 13'ü iyi ve \% 1,9 'u çok iyi düzeyindedir.

Yazılı Anlatımda Planlama Becerisi Çözümleyici Puanlama Anahtarının Giriş Boyutuna ilişkin Bulgular

Yazılı anlatımda planlama becerisi çözümleyici puanlama anahtarının giriş bölümü boyutuna ilişkin veriler aşağıdaki tabloda verilmiştir.

Tablo 13

Yazılı Anlatımda Planlama Becerisi Çözümleyici Puanlama Anahtarının Giriş Bölümü Boyutuna iliş̧kin Frekans ve Yüzde Değerleri

Madde Derecelendirme


8. Sınıf Öğrencilerinin Yazılı Anlatımda Planlamaya Yönelik Görüş ve Becerilerinin Değerlendirilmesi

\begin{tabular}{|c|c|c|c|c|c|c|c|c|c|c|c|c|}
\hline \multirow{3}{*}{ Giriş } & \multicolumn{2}{|c|}{ Çok Yetersiz } & \multicolumn{2}{|c|}{ Yetersiz } & \multicolumn{2}{|c|}{ Orta } & \multicolumn{2}{|c|}{ İyi } & \multicolumn{2}{|c|}{ Çok İyi } & \multicolumn{2}{|c|}{ TOPLAM } \\
\hline & $\mathrm{F}$ & $\%$ & $F$ & $\%$ & $\mathrm{~F}$ & $\%$ & $f$ & $\%$ & $f$ & $\%$ & $f$ & $\%$ \\
\hline & 95 & 25,7 & 160 & 43,2 & 78 & 21,1 & 29 & 7,8 & 8 & 2,2 & 370 & 100 \\
\hline
\end{tabular}

Tablo 13'e göre çözümleyici puanlama anahtarının giriş boyutunda öğrencilerin \% 25,7'si çok yetersiz, \% 43,2'si yetersiz, \% 21,1'i orta, \% 7,8'i iyi ve \% 2,2'si çok iyi düzeyindedir.

\section{Yazılı Anlatımda Planlama Becerisi Çözümleyici Puanlama Anahtarının Gelişme Bölümü Boyutuna ilişkin Bulgular}

Yazılı anlatımda planlama becerisi çözümleyici puanlama anahtarının gelişme bölümü boyutuna ilişkin veriler aşağıdaki tabloda verilmiştir.

Tablo 14

Çözümleyici Puanlama Anahtarının Gelişme Boyutuna illişkin Frekans ve Yüzde Değerleri

\begin{tabular}{|c|c|c|c|c|c|c|c|c|c|c|c|c|}
\hline \multirow{3}{*}{$\begin{array}{l}\text { Madde } \\
\text { Gelişme }\end{array}$} & \multicolumn{12}{|c|}{ Derecelendirme } \\
\hline & \multicolumn{2}{|c|}{ Çok Yetersiz } & \multicolumn{2}{|c|}{ Yetersiz } & \multicolumn{2}{|c|}{ Orta } & \multicolumn{2}{|c|}{$\overline{\text { İyi }}$} & \multicolumn{2}{|c|}{ Çok İyi } & \multicolumn{2}{|c|}{ TOPLAM } \\
\hline & $\mathrm{F}$ & $\%$ & $f$ & $\%$ & $f$ & $\%$ & $f$ & $\%$ & f & $\%$ & f & $\%$ \\
\hline & 57 & 15,4 & 160 & 43,2 & 99 & 26,8 & 45 & 12,2 & 9 & 2,4 & 370 & 100 \\
\hline
\end{tabular}

Tablo 14'e göre çözümleyici puanlama anahtarının gelişme boyutunda öğrencilerin \% 15,4'ü çok yetersiz, \% 43,2'si yetersiz, \% 26,8'i orta, \% 12,2'si iyi ve \% 2,4'ü çok iyi düzeyindedir.

\section{Yazılı Anlatımda Planlama Becerisi Çözümleyici Puanlama Anahtarının Sonuç Bölümü Boyutuna ilişkin Bulgular}

Yazılı anlatımda planlama becerisi çözümleyici puanlama anahtarının sonuç bölümü boyutuna ilişkin veriler aşağıdaki tabloda verilmiştir.

Tablo 15

Çözümleyici Puanlama Anahtarının Sonuç Bölümü Boyutuna Iliş̧in Frekans ve Yüzde Değerleri

\begin{tabular}{|c|c|c|c|c|c|c|c|c|c|c|c|c|}
\hline \multirow[t]{2}{*}{ Madde } & \multicolumn{12}{|c|}{ Derecelendirme } \\
\hline & \multicolumn{2}{|c|}{ Çok Yetersiz } & \multicolumn{2}{|c|}{ Yetersiz } & \multicolumn{2}{|c|}{ Orta } & \multicolumn{2}{|c|}{ İyi } & \multicolumn{2}{|c|}{ Çok İyi } & \multicolumn{2}{|c|}{ TOPLAM } \\
\hline \multirow[t]{2}{*}{ Sonuç } & $\mathrm{F}$ & $\%$ & $\mathrm{~F}$ & $\%$ & $f$ & $\%$ & $f$ & $\%$ & $f$ & $\%$ & $f$ & $\%$ \\
\hline & 131 & 35,4 & 132 & 35,7 & 74 & 20,0 & 29 & 7,8 & 4 & 1,1 & 370 & 100 \\
\hline
\end{tabular}

Tablo 15'e göre çözümleyici puanlama anahtarının sonuç boyutunda öğrencilerin \% 35,4'ü çok yetersiz, \% 35,7'si yetersiz, \% 20'si orta, \% 7,8'i iyi ve \% 1,1'i çok iyi düzeyindedir.

\section{Tartışma, Sonuç ve Öneriler}

Bu çalışmada 8. sınıf öğrencilerinin yazılı anlatımda planlama becerileri "Yazılı Anlatımda Planlama Becerisi Çözümleyici Puanlama Anahtarı" ile belirlenmeye çalışılmıştır. Bu puanlama anahtarı, başlık, konu, ana düşünceler ve yardımcı düşünceler, anlatım biçimleri ve düşünceyi geliştirme yolları, giriş, gelişme ve sonuç olmak üzere toplam 7 boyuttan meydana gelmektedir. Aşağıda bu boyutların her birine ilişkin ulaşılan bulgular tartışılmaktadır.

\section{Sınıf Öğrencilerinin Yazııı Anlatımda Planlama Becerileri Başlık Boyutuna ilişskin Tartışma ve Sonuç}

Çözümleyici puanlama anahtarının başlık boyutunda değerlendirilen planlama becerileri; yazıda başlık kullanma, yazının konusu hakkında bilgi verme, kısa, öz ve orijinal olma, okuyucunun ilgi ve dikkatini çekme, yazıda iletilmek istenen ana düşünceye uygun olma gibi özelliklerden oluşmaktadır. 8. sınıf öğrencilerinin çözümleyici puanlama anahtarının başlık boyutunu planlama becerileri bu özellikler doğrultusunda $\% 13,8$ çok yetersiz, $\% 22,2$ yetersiz, $\% 47,3$ orta, $\% 15,7$ iyi ve $\% 1,1$ çok iyi 
düzeyinde tespit edilmiştir. Bu bulgulara göre öğrencilerin yazılı anlatımda başlık unsurunu planlama becerileri açısından yaklaşık yarısı orta derecededir. Yani öğrencilerin yarısı yazılı anlatım çalışmalarında başlık kullanmaktadır. Ayrıca kullanılan bu başlık okuyucuya az da olsa yazının konusu hakkında bilgi vermektedir. Başlık kısa ancak öz ve orijinal değil, okuyucunun ilgisini ve dikkatini çekmekten biraz uzak ve yazının ana düşüncesine tam anlamıyla uygun değildir. Çalışmada başlık boyutunun planlanmasıyla ilgili ulaşılan ilgi çekici bir sonuç da öğrencilerin $\% 36$ 'sının yetersiz ve çok yetersiz düzeyde olmasıdır. Başılı kullanımında yetersiz ve çok yetersiz düzeyin yüksek oranda çıkmasının sebeplerinin başında öğrencilerin yazıya başlık yazmayı unutması gelmektedir. Hatta öğrencilerin kompozisyon yazma sürecinde öğretmenlere yönelttiği soruların geneli başlığın konulup konulmaması gerektiği yönündedir. Kimi öğrenciler hatırlatma ile başlık kullanımına gitmektedir. Ayrıca öğrencilerin, başlığın yazıya başlamadan önce mi yoksa yazıyı bitirdikten sonra ortaya çıkan yazıya göre mi konulması gerektiğini bilmemesi, başlık boyutunda yetersiz kalınmasına sebep olabilmektedir. Genel görüş, başlığın, yazı tamamlandıktan sonra yazının gelişimine göre şekillenmesidir ancak öğrenciler yazıya başlamadan başlığı belirlemektedir. Bu yanlış, metnin başlı̆ın ifade ettiği konudan uzaklaşmasına sebep olmakta hatta yazıyı başlıktan çok alakasız bir konuma sürükleyebilmektedir.

Başlık boyutunun planlanmasına bakıldığında "iyi" düzeyde sayılabilecek öğrencilerin oran olarak oldukça az olduğu hatta "çok iyi" düzeyde olan öğrencilerin oranının sadece $\% 1,1$ 'de kaldığı görülmektedir. Bu durum, 8. sınıf öğrencilerinin yazılı anlatımda planlamanın başlık boyutunda başarısız olduğunun bir göstergesidir. Başlığın orijinal, özgün ve ilgi çekmekten uzak olması; ele alınacak yazı için verilen konunun doğrudan başlık olarak kullanılması öğrencilerin başlık boyutunda yetersizliğinin sebepleri arasında sayılabilir. "Çok iyi" düzeyde olan öğrencilerin oranının bu derece az olmasının altında yatan sebeplerden biri de öğrencilerin başlık üzerinde yeterince düşünmeyip yaratıcılığı ve özgünlüğü başlıkta ortaya koymamasıdır. Alkan (2007: 59), yazılı anlatım becerilerini incelerken ele aldığı "Yazıya ilgi çekici, kısa ve konunun özüne uygun başlı̆ın konulmaması." maddesinde öğrencilerin \%83,3'ünün 0 hata puanı; $\% 16,7$ 'sinin 5 hata puanı aldığını saptamıştır. Buna göre verilen hata puanları sayısal değerlerinin aritmetik ortalamasının 0.83 çıktığını ve bu maddede öğrencilerin genel çoğunluğunun hata yapmadığını belirleyerek bizim çalışmamızda elde ettiğimiz bulgularla örtüşmeyen farklı bir sonuca ulaşmıştır. Avcı (2006: 51) tarafından yapılan çalışmada 10 okuldan seçilen öğrencilerin yazılı anlatımda konuya uygun başlık kullanma becerileri değerlendirilmiş ve 100 puan üzerinden ortalama 72 puanlık bir başarı düzeyi tespit edilmiştir. Bu bulgu, bizim çalışmamızda ulaşılan bulgularla benzerlik göstermemektedir. Çünkü öğrencilerin yarıya yakını başlık boyutu doğrultusunda orta düzeyde; \%36'ık önemli bir oranı da yetersiz ve çok yetersiz düzeyde bulunmuştur. Bu noktada öğrencilerin kendi yazılı anlatım ürünlerini düzeltme ve değerlendirme alışkanlıkları ile öğretmenin öğrencilere bu konuda verdiği geri bildirimler önem taşımaktadır.

\section{Sınıf Öğrencilerinin Yazılı Anlatımda Planlama Becerileri Konu Boyutuna İlişkin Tartışma ve Sonuç}

Çözümleyici puanlama anahtarının konu boyutunda değerlendirilen planlama becerileri; yazıda konu ile ilgili yeterince bilgi ortaya koyma, konunun sınırlandırılmasını sağlama ile hangi açıdan ele alınacağını tespit etme, konuyu seçilebilecek bir biçimde ele alma ve yazıda anahtar kelimeleri belirgin bir biçimde ortaya koyma gibi özelliklerden oluşmaktadır. 8. sınıf öğrencilerinin çözümleyici puanlama anahtarının konu boyutunu planlama becerileri bu özellikler doğrultusunda $\% 13,5^{\prime} \mathrm{i}$ çok yetersiz, $\% 40,3^{\prime}$ ü yetersiz, \%26,8'i orta, $\% 15,9^{\prime}$ u iyi ve $\% 3,5^{\prime} i$ çok iyi düzeyinde tespit edilmiştir. Bu bulgulara bakıldığında \%40,3 ile öğrencilerin yarısına yakınının konu boyutunda yetersiz olduğu görülmektedir. Başka bir deyişle araştırmaya katılan öğrencilerin yarısına yakını yazıda konunun sınırlandırıımasını sağlamamakta, hangi açıdan ele alınacağını tespit etmemekte ve konuyu seçilebilecek bir biçimde ortaya koymamaktadır; ayrıca yazıda anahtar kelimeler belirgin değil, konu ile ilgili bilgiler de yetersizdir. Çözümleyici puanlama anahtarının konu boyutunda "yetersiz" ile "çok yetersiz" düzeyde olanlar birlikte düşünüldüğünde ortaya $\% 53,8$ gibi yüksek bir oran ortaya çıkmaktadır. Bu durum öğrencilerin yarısından fazlasının konu boyutundaki başarısının yeterli düzeyde olmadığını göstermektedir. "Çok iyi" düzeyin \%3,5 gibi düşük bir oranda kalması da bu durumu destekler niteliktedir. 
Yazılı anlatımda başarıyı artıran ve besleyen kaynaklar olan okumak, gözlem yapmak, düşünmek, yaşantı ve deneyim gibi etkenler yazıda konuyu destekleyici özelliktedir. Ancak genel olarak öğrencilerde okuma ile düşünme alışkanlıklarının, gözlem yapma yeteneğinin ve yaşantılarla tecrübe edinmenin istenilen düzeyde olmadığı bilinmektedir. Okumaktan, düşünmekten, gözlem yapmaktan, farklı yaşantılarla deneyim kazanmaktan yoksunluk yazıda ele alınan konu hakkında yeterli bilgiye sahip olunmamasına yol açmaktadır. Bilginin yetersiz olması yazının doyurucu olmaktan uzak ve sığ olmasına yol açmaktadır. Bu doğrultuda öğrencilere öncelikle okuma alışkanlığı kazandıııması gerektiği artık çok bilinen bir gerçektir. Çelikpazu (2006: 80) 6. sınıf öğrencilerinin yazılı anlatım becerilerini araştırması sonucunda okuma alışkanlığının önemine dikkat çekmiş; okuma alışkanlığı ve zevki kazanmamış öğrencilerin duygu, düşünce ve isteklerini istedikleri gibi anlatamadıklarını belirtmiştir. Ayrıca Coşkun (2006: 99-100)'un çalışmasında öğrencilerin yazılı anlatım becerilerinin okumuş oldukları kitap sayısı değişkenine göre anlamlı bir farklıık göstermekte olduğu ortaya çıkmıştır. Koçak (2005: 56) da okuma alışkanlığının yazııı anlatım becerisine olumlu katkısı olduğunu tespit etmiş ve çok kitap okuyan öğrencilerin yazılı anlatımlarının, az kitap okuyan öğrencilerin yazılı anlatımlarına göre daha başarılı olduklarını belirtmiştir.

Yazılı anlatımda planlamanın konu boyutunda önemle üzerinde durulması gereken noktalardan biri de konunun sınırlandıııması ve hangi açıdan ele alınacağının belirlenmesidir. Planlamada öğrenci konu ile ilgili bilgilerin tamamını ortaya döker, konunun hangi yönüyle ele alınacağını tespit eder ve bu doğrultuda yazısında kullanacağını bilgileri seçmeye başlar. Bu, konuda sınırlandırmayı sağlar; ancak öğrenci, yazıya başlamadan önce, verilen konuyu kısaca düşünür ve aklına gelen bilgileri gelişigüzel bir şekilde ortaya dökerek yazısını oluşturmaya çalışır. Bu durum; yazıda konunun dağılmasına, bir birlik ve bütünlük oluşmamasına, konudan uzaklaşılmasına, konunun tam anlamıyla ne olduğunun ortaya çıkmamasına neden olmaktadır. Bu noktada öğrencilere konunun sınırlandırılmasının nasıl sağlanacağı, konunun belli bir açıdan ne şekilde ele alınması gerektiği yazma etkinliklerinde uygulamalı olarak kavratılmalı ve bu çalışma her yazma etkinliğinde tekrarlanmalıdır. Alkan (2007: 57), yazılı anlatımda konunun sınırlandırılmasını "Konunun belli görüş açılarına göre sınırlandııımaması." maddesine göre incelemiş ve öğrencilerin \%23,4'ünün 0 hata puanı, \%41,1'inin 1 hata puanı, \%31,6'sının 2 hata puanı, \%3,6'sının 3 hata puanı, \%0,3'ünün 4 hata puanı aldığını belirlemiştir. Buna göre verilen hata puanları sayısal değerlerinin aritmetik ortalamasının 1.16 çıktığını ve bu maddede öğrencilerin genel çoğunluğunun 1 hata puanı aldığını saptamıştır. Bu bulgular öğrencilerin çoğunluğunun konunun sınırlandırıımasında hata yaptığı sonucunu ortaya koymaktadır. Bu sonuç, çalışmamızdaki konu boyutu bulgularıyla örtüşen niteliktedir.

\section{Sınıf Öğrencilerinin Yazılı Anlatımda Planlama Becerileri Ana Düşünce ve Yardımcı Düşünceler Boyutuna İlişkin Tartışma ve Sonuç}

Çözümleyici puanlama anahtarının ana düşünce ve yardımcı düşünceler boyutunda değerlendirilen planlama becerileri; yazıda ana düşünce ve yardımcı düşüncelerin belirgin, açık bir biçimde ortaya konulması, yardımcı fikirler arasında bağlantı sağlanarak yazıda bütünlüğün gerçekleştirilmesi gibi özelliklerden oluşmaktadır. 8. sınıf öğrencilerinin çözümleyici puanlama anahtarının ana düşünce ve yardımcı düşünceler boyutunu planlama becerileri bu özellikler doğrultusunda \%13,5'i çok yetersiz, \%44,3'ü yetersiz, \%25,7'si orta, \%13,8'i iyi ve \%2,7'si çok iyi düzeyinde tespit edilmiştir. Bu bulgulara göre öğrencilerin yarıya yakını yazılı anlatımın ana düşünce ve yardımcı düşünceler boyutunda yetersiz düzeydedir. Bu yetersizliğin en önemli sebeplerinden biri öğrencilerin yazma sürecinde yazının amacını ortaya koyacak bir ana düşünce belirlememesidir. Yazılı anlatımda yazının ana düşüncesini belirlemek ve yazıyı bu ana düşünce çerçevesinde geliştirmek önemlidir. Amaçsız bir biçimde yazıya başlamak; ana düşünceyi destekleyecek yardımcı fikirlerin gelişigüzel bir şekilde sıralanmasına ve yazının iletmek istediği düşüncenin açık ve belirgin olmaktan uzak kalmasına yol açar. Alkan (2007: 58) "Ana düşüncenin yardımcı düşüncelerle desteklenmemesi." maddesiyle inceleme yaparak ana düşünce ve yardımcı düşünceler boyutu üzerinde durmuş ve öğrencilerin "ana düşüncenin yardımcı düşüncelerle desteklenmesi" konusunda yetersiz olduğu sonucuna varmışlardır. 


\section{Sınıf Öğrencilerinin Yazılı Anlatımda Planlama Becerileri Anlatım Biçimleri ve Düşünceyi Geliştirme Yolları Boyutuna İlişkin Tartışma ve Sonuç}

Çözümleyici puanlama anahtarının anlatım biçimleri ve düşünceyi geliştirme yolları boyutunda değerlendirilen planlama becerileri; yazıda anlatım biçimlerinin belirgin bir şekilde kullanılması, kullanılan anlatım biçimlerinin yazının amacına uygun olması ve dil açısından uygunluk taşıması, yazıda farklı türden düşünceyi geliştirme yollarına başvurulması, bu düşünceyi geliştirme yollarının ustalıkla kullanııması gibi özelliklerden oluşmaktadır. 8. sınıf öğrencilerinin çözümleyici puanlama anahtarının anlatım biçimleri ve düşünceyi geliştirme yolları boyutunu planlama becerileri bu özellikler doğrultusunda $\% 15,7^{\prime}$ si çok yetersiz, $\% 47,8^{\prime}$ i yetersiz, $\% 21,6$ 'sı orta, $\% 13^{\prime}$ ü iyi ve \%1,9'u çok iyi düzeyinde tespit edilmiştir. Bu bulgular ışığında öğrencilerin \%47,8 ile neredeyse yarısı "yetersiz" düzeydedir. Başka bir deyişle araştırmaya katılan öğrencilerin yarıya yakını, yazıda anlatım biçimlerini kullanmış ancak bu anlatım biçimlerini yazının amacına uygun kullanmamış, anlatım biçimlerinin dil açısından uygunluğunu yetersiz bir biçimde ele almış ve bu öğrencilerin yazıda başvurduğu düşünceyi geliştirme yolları yetersiz kalmıştır. Bu boyutta başarısız olmanın temelinde öğrencilerin anlatım biçimleri ve düşünceyi geliştirme yollarını yalnızca teorik boyutta öğrenip uygulama yapmamaları yatmaktadır. Öğrencilere sadece örnek bir paragraf üzerinde çalışma yapılarak bu paragrafın hangi anlatım biçimiyle yazıldığı, bu paragrafta hangi düşünceyi geliştirme yollarının kullanıldığı gösterilmektedir. Öğrenci, paragrafın hangi anlatım biçimiyle yazıldığını nasıl anlayabileceğine ve paragrafta hangi düşünceyi geliştirme yollarının kullanıldığını bulmaya yönelik bilgiler öğrenmekten öteye geçememektedir. Bu bilgileri kavrayan öğrenciden, belirli bir anlatım biçiminde ve bu anlatım biçimine uygun birkaç düşünceyi geliştirme yolunu da kullanarak bir paragraf yazması istendiğinde o öğrencide aynı başarı gözlenememektedir. Akbayır (2006: 69), araştırmasında uygulamaya katılan 20 kişilik öğretmen adayına, ÖSYM tarafından 1981-2005 yılları arasında sorulan 43 soru dağıtıp 45 dakika süre vermiş; öğrencilerin, konuyla ilgili test sorularında \%90'ın üzerinde bir başarı sağladıklarını görmüştür. Sonuç olarak anlatım biçimleriyle ilgili test sorularını rahatılıkla çözebilen öğrencilerin, anlatım biçimlerinin kuramsal yönüyle ilgili uygulamalı sorularda oldukça zorlandığı sonucuna varmıştır. Kısacası öğrenciler, anlatım biçimleri ve düşünceyi geliştirme yollarının ne olduğunu bilmekte ancak uygulama yapamamaktadır. Bu yüzden yazma çalışması yapılırken planlamanın bir boyutu olan anlatım biçimleri ve düşünceyi geliştirme yollarını kullanmada uygulama becerisi kazanmasına yönelik çalışmalara sıklıkla yer verilmelidir.

\section{Sınıf Öğrencilerinin Yazılı Anlatımda Planlama Becerileri Giriş Boyutuna ilişkin Tartışma ve Sonuç}

Çözümleyici puanlama anahtarının giriş boyutunda değerlendirilen planlama becerileri; yazıda giriş bölümünün bulunması, giriş bölümünün okuyucunun ilgi ve dikkatini çekecek nitelikte olması, metnin bütününe dair bir fikir vermesi, metne doğrudan giriş yapma yerine farklı türden bir giriş yapma yolu kullanılması gibi özelliklerden oluşmaktadır. 8. sınıf öğrencilerinin çözümleyici puanlama anahtarının giriş boyutunu planlama becerileri bu özellikler doğrultusunda \%25,7'si çok yetersiz, $\% 43,2$ 'si yetersiz, $\% 21,1^{\prime}$ i orta, $\% 7,8$ 'i iyi ve $\% 2,2$ 'si çok iyi düzeyindedir. Bu boyutta $\% 43,2$ ile en yüksek oran "yetersiz" düzeydedir. Başka bir deyişle öğrencilerin \%43,2'sinin yazısında giriş bölümü bulunmaktadır ancak giriş bölümü okuyucunun ilgi ve dikkatini çekecek nitelikte değildir, metnin bütününe dair bir fikir vermemektedir ve bu öğrenciler metne doğrudan giriş yapmıştır. Bu bulgularda dikkati çeken nokta "çok yetersiz" düzeyin öğrencilerin 4'te 1'ine tekabül edecek oranda olmasıdır. Yani yazıların \%25,7'sinde giriş bölümü bulunmamakta ya da giriş paragrafı yazının giriş bölümünde yer almamaktadır.

Yazılı anlatım çalışmalarında ele alınacak konunun belirlenmesinden sonra öğrenciler kısa bir düşünme sürecine girerler. Bu süreçte öğrenciler neleri yazabileceğinin yanında en çok yazıya nasıl bir giriş yapabileceğini düşünürler. Hatta öğrencilerin yazma öncesi bu düşünme sürecinde "aklıma bir şey gelmiyor" yakınmasının altında yazının başlangııını yapmadaki çektikleri zorluk gelmektedir. Giriş boyutuna ilişkin bulgulara baktığımızda "yetersiz" ve "çok yetersiz" düzeylerin toplamda \%68,9 ile yüksek bir oranda çıkması, öğrencilerin yazının giriş bölümünü oluşturmadaki bu zorlanmalarını gösterir niteliktedir. 
Yazıda giriş bölümü oluşturmada karşılaşılan eksikliklerin başında bu bölümün farklı bir giriş yoluyla oluşturulup okuyucunun ilgi ve dikkatini yazıya yeterince çekememek gelmektedir. Yazının başlıktan sonraki vitrini konumunda olan giriş bölümü çoğunlukla basmakalıp söz, ifade ve tanımlarla başlamaktadır. Bu durumda öğrencilerin yaratıcılıklarının yeterince geliştirilmediği ve kullanabileceği farklı giriş yollarının uygulamalı kavratılmadığı sonucuna varılabilir.

\section{Sınıf Öğrencilerinin Yazılı Anlatımda Planlama Becerileri Gelişme Boyutuna iliş̧kin Tartışma ve Sonuç}

Çözümleyici puanlama anahtarının gelişme boyutunda değerlendirilen planlama becerileri; yazıda gelişme bölümünün bulunması, gelişme bölümünde düşüncelerin belli bir sıralamaya göre düzenlenmesi, yazının anlaşılır nitelikte olması, düşüncelerin gereksiz bir biçimde tekrarına düşülmemesi, ifade edilen fikirler arasında mantıklı bağların kurulması, ifadelerin okurun ilgisini çekecek nitelikte olması, yazarın amacını açıkça ortaya koyması, geliştirilen düşüncelerde ve bu düşüncelerin anlatımında orijinalliğin sağlanması gibi özelliklerden oluşmaktadır. 8. sınıf öğrencilerinin çözümleyici puanlama anahtarının gelişme boyutunu planlama becerileri bu özellikler doğrultusunda $\% 15,4$ 'ü çok yetersiz, \%43,2'si yetersiz, $\% 26,8^{\prime}$ i orta, $\% 12,2^{\prime}$ si iyi ve $\% 2,4^{\prime}$ ü çok iyi düzeyindedir. Bu bulgulara bakıldığında en yüksek oranın \%43,2 ile yetersiz düzeyde olduğu görülmektedir. Yani bu öğrencilerin yazısında gelişme bölümü bulunmakta ancak gelişme bölümünde düşüncelerin belli bir sıralamaya göre düzenlenmesi çok yetersizdir ve yazı anlaşılır değildir. Bu öğrenciler düşüncelerin gereksiz bir biçimde tekrarına düşmüştür, gelişme bölümünde ifade edilen fikirler arasında mantıklı bağlar kurmada çok yetersizdirler, ifadeler okurun ilgisini çekecek niteliğe sahip değildir, öğrenciler amacını açıkça ortaya koymada çok yetersizdir, geliştirilen düşüncelerde ve bu düşüncelerin anlatımında bir orijinallik sağlayamamışlardır.

\section{Sınıf Öğrencilerinin Yazılı Anlatımda Planlama Becerileri Sonuç Boyutuna i̇lişkin Tartışma ve Sonuç}

Çözümleyici puanlama anahtarının sonuç boyutunda değerlendirilen planlama becerileri; yazıda sonuç bölümünün bulunması, sonuç bölümünde konunun etkili bir biçimde sonuçlandırılması, okuyucuda beliren sorulara cevap verilmesi, sonuç bölümünün yazının genelinde anlatılanları özetler nitelikte olması ve yazının tamamında anlatılanlarla çelişmemesi gibi özelliklerden oluşmaktadır. 8 . sınıf öğrencilerinin çözümleyici puanlama anahtarının sonuç boyutunu planlama becerileri bu özellikler doğrultusunda \%35,4'ü çok yetersiz, \%35,7'si yetersiz, \%20'si orta, \%7,8'i iyi ve \%1,1'i çok iyi düzeyindedir. Yazılı anlatımda planlama sonuç boyutu bulgularında ilk dikkati çeken "çok yetersiz" düzeyin \%35,4 ile çok yüksek olmasıdır. Bu, öğrencilerin \%35,4'ünün yazısında sonuç bölümünün bulunmadığını ya da bulunduğunu ancak sonuç bölümünde konunun etkili bir biçimde sonuçlandırılmadığını, okuyucuda beliren sorulara cevap verilmediğini, sonuç bölümünün yazının genelinde anlatılanları özetlemediğini ve yazının tamamında anlatılanlarla çeliştiğini gösterir. Hatta "çok yetersiz" düzey ile "yetersiz" düzey birlikte ele alındığında toplamda öğrencilerin \%71,1'ini oluşturduğu görülmektedir. Bu düzeylerin oranının bu derece yüksek çıkması öğrencilerin yazılı anlatımda planlama sonuç boyutunda başarısız olduğunun göstergesidir.

Kompozisyon yazma denilince öğrencilerin aklına ilk olarak giriş, gelişme ve sonuç kavramları gelir. Öğrenci yazının planlanmasını ve oluşturulmasını yalnızca bu bölümlere bağlı olarak görür. Öğrenciler yazının başlangıcına bir giriş paragrafının, girişten biraz daha uzun bir paragrafla gelişme bölümünün ve yazının sonunda bir satır başı daha yapılıp birkaç cümle eklenerek sonuç bölümünün yazıımasıyla yazının tamamlandığını ve verilen görevin hakkıyla bitirildiğini düşünürler. Öğrenci yazıyı yalnızca bu üç boyutuyla düşünür ve planlamadaki başıık, konu, ana düşünce, yardımcı düşünceler, anlatım biçimi, düşünceyi geliştirme yolları gibi boyutlarını göz ardı ederler. Ancak öğrencilerin hem göz ardı ettiği bu boyutlarda hem de teorik olarak en çok bildiği giriş, gelişme, sonuç boyutlarında yeterli düzeyde bir başarı sağlamadıkları bu bulgulardan da görülebilmektedir.

Araştırmada elde edilen bulgular genel olarak değerlendirildiğinde yazılı anlatımı planlamada, 8. sınıf öğrencilerinin istenilen düzeyde bir başarı sağlayamadıkları görülmektedir. Her bir boyutta çoğunlukla "çok yetersiz" ve "yetersiz" düzeylerin toplamda \%50'nin üzerinde olması -başlık boyutu 
hariç (\%36)- ve "iyi" ile "çok iyi" düzeylerin toplamda çok düşük bir oranda kalması öğrencilerin bu konudaki yetersizliğini göstermektedir. Bulgular ışığında, öğrenciler, "iyi" ve "çok iyi" düzeylerinin toplamda \%19,4 olması ile öğrencilerin en çok konu boyutunda başarılı olduğu; "yetersiz" ve "çok yetersiz" düzeylerinin toplamda \%71,1 olması ile öğrencilerin en çok sonuç boyutunda başarısız olduğu da saptanmıştır. Ayrıca başlık hariç $(\% 47,3)$ bütün boyutlarda "orta" düzeyin \%20 ila \%26,8 oranı aralığında kalması da dikkat çeken başka bir ayrıntıdır.

Bu sonuçlara göre öğretmenlere, öğretim programlarına, ders kitaplarına ve araştırmacılara yönelik şu önerilerde bulunulabilir:

\section{Öğretmenlere Yönelik Öneriler}

\section{Öneriler}

- Öğretmenler yazmayı bir süreç olarak görmeli ve yazılı anlatım sürecinin aşamalarından olan planlamayı öğrencilere kavratmalıdır.

- Öğretmenler sınıf içi etkinliklerde sık sık yazma çalışması yaptırmalı ve yazılı anlatımı planlama çalışmalarına her yazma uygulamasında yer vermelidir.

- Öğretmenler yazılı anlatımda planlamayı yalnızca giriş, gelişme ve sonuç boyutlarından ibaret sanan öğrencilere bu boyutların yanında başlık, konu, ana düşünce, yardımcı düşünceler, anlatım biçimleri, düşünceyi geliştirme yolları gibi boyutların da olduğunu anlatmalı ve planlamada bu boyutların nasıl ele alınacağını kavratmalıdır.

- Öğretmenler yazılı anlatımda planlama sürecinde öğrencilerin uygulamalarını incelemeli; yanlışlarını düzeltme yönünde öğrencilere anında geri bildirim ve dönüt vermelidir.

- Öğretmenler iyi planlanmış bir yazıyı örnek olarak göstermelidir. Ayrıca yazılı anlatımı planlama çalışmalarında kimi zaman kendisi çalışmaya bizzat katılarak iyi planlanmış bir metin ortaya çıkarmalı ve bu şekilde öğrencilere örnek olmalıdır.

\section{Öğretim Programlarına Yönelik Öneriler}

- Eğitim fakültelerinde yazma eğitimi, yazılı anlatım gibi alan eğitimi derslerinde yazılı anlatımda planlama ile ilgili bilgilere yer verilmelidir. Bu bilgiler Türkçe öğretmeni adaylarına iyice kavratılmalıdır.

- Eğitim fakültelerinde Türkçe öğretmeni adaylarına yazılı anlatımda planlamaya yönelik verilen teorik bilgiler uygulamalarla desteklenmelidir.

- Ölçme ve değerlendirmede çoktan seçmeli testlerin yanı sıra öğrencinin öğretmen adaylarının kendilerini yazarak da ifade edebileceği sınavlar geliştirilmelidir.

\section{Ders Kitaplarına ve Öğretim Materyallerine Yönelik Öneriler}

Türkçe derslerinde yazılı anlatım etkinlikleri yalnızca Türkçe çalışma kitaplarında yer almaktadır. Bu etkinliklerin nasıl yapılacağı, öğrencilerin ve öğretmenlerin etkinlikte neler yapması gerektiği öğretmen kılavuz kitabında yer almaktadır. Ancak bu çalışmalarda bazı eksiklikler ve aksaklıklar bulunmaktadır. Ders kitaplarıyla ilgili şu öneriler getirilebilir:

- Türkçe öğrenci çalışma kitaplarında yer alan yazma etkinlikleri yazılı anlatımda planlamayı içerecek bir biçimde düzenlenmelidir.

- Türkçe ders kitaplarında yazılı anlatımı planlamayla ilgili teorik bilgiler yer almalıdır.

\section{Araştırmacılara Yönelik Öneriler}

- Daha küçük örneklem gruplarıyla çalışılıp yazılı anlatımda planlamanın boyutları ayrı ayrı incelenerek değerlendirilebilir.

- Yazılı anlatımı planlama konusunda eğitim verilmiş bir grup öğrenci ile eğitim verilmemiş bir grup öğrencinin planlama becerilerini karşılaştıran bir çalışma yapılabilir. 


\section{Kaynaklar}

Ağca, H. (2006). Yazılı anlatım. Ankara: Gündüz Eğitim Yayıncılık.

Akbayır, S. (2006). Yazılı anlatım biçimlerinin yazma becerisi edinimindeki işlevleri (Yüksek lisans tezi). On Dokuz Mayıs Üniversitesi, Samsun.

Aktaş, Ş. ve Gündüz, O. (2002). Yazılı ve sözlü anlatım. Ankara: Akçağ Yayınları.

Alkan, Z. N. (2007). Ilköğretim beşinci sınıf öğrencilerinin yazılı anlatım hataları (Yüksek lisans tezi). Osmangazi Üniversitesi Sosyal Bilimler Enstitüsü, Eskişehir.

Avcı, E. (2006). Ilköğretim 8. sınıf öğrencilerinin yaptıkları yazılı anlatım yanlışlarının incelenmesi (Yüksek lisans tezi). Ankara Üniversitesi Sosyal Bilimler Enstitüsü, Ankara.

Babacan, M. (2007). Yazılı ve sözlü anlatım. İstanbul: 3F Yayınevi.

Bağcı, H. (2019). İlk ve Orta Öğretim Öğrencilerinin Yazılı Anlatımda Planlama Becerileri Üzerine Bir Inceleme. Turkish Studies - International Periodical For The Languages, Literature and History of Turkish or Turkic Volume 14/3, 411-424.

Bayramıçlılar, Ö., Tosun, N. S. ve Ak, N. (1990). Sözlü yazılı ve bilimsel anlatım tekniği. İstanbul: İstanbul Teknik Üniversitesi Vakfı Yayın No: 31.

Bülbül, A. R. (2000). Yazılı anlatım ve yazı türleri. Ankara: Nobel Yayın Dağıtım.

Can, R. (2012). Ortaöğretim öğrencilerinin yazılı anlatımlarında paragraf düzeyinde bağdaşıklık ve tutarlıık (Doktora tezi). Gazi Üniversitesi, Ankara.

Çakır, Ö. (2003). Yazma Öğretiminde Süreç Yaklaşımına Dayalı Programın Yazıı Anlatım Becerisini Geliştirmedeki Rolü: Mersin Üniversitesi Eğitim Fakültesi Örneği. TÖMER Dil Dergisi, 122, 31 51.

Çelikpazu, E. (2006). Erzurum merkez ilçe ilköğretim 6.sınıf öğrencilerinin yazılı anlatım becerileri üzerine bir araştırma (Yüksek lisans tezi). Atatürk Üniversitesi Sosyal Bilimler Enstitüsü, Erzurum.

Coşkun, i. (2006). illköğretim 5. sınıf öğrencilerinin kompozisyon yazma becerileri üzerine bir araştırma (Yüksek lisans tezi). Marmara Üniversitesi Eğitim Bilimleri Enstitüsü, İstanbul.

Kantemir, E. (1997). Yazılı ve sözlü anlatım. Ankara: Engin Yayınevi.

Karasar, N. (2009). Bilimsel araştırma yöntemi. Ankara: Nobel Yayıncılık.

Karatay, H. (2011). Yazma eğitimi. (Ed. Murat Özbay). Süreç temelli yazma modelleri: planlı yazma ve değerlendirme. Ankara: Pegem Akademi Yayıncılık. s. 21-42.

Koçak, A. (2005). Bolu ili ilköğretim beşinci ve sekizinci sınıf öğrencilerinin yazılı anlatım becerileri üzerine bir araştırma (Yayımlanmış yüksek lisans tezi) Abant İzzet Baysal Üniversitesi Sosyal Bilimler Enstitüsü Türkçe Eğitimi Ana Bilim Dalı, Bolu.

Maltepe, S. (2006). Yaratııı yazma yaklaşımı açısından Türkçe dersindeki yazma süreçlerinin ve ürünlerinin değerlendirilmesi (Doktora tezi) Ankara Üniversitesi Sosyal Bilimler Enstitüsü Türkçe Öğretimi ve Eğitimi Ana Bilim Dalı, Ankara.

Oral, G. (2008). Yine yazı yazıyoruz (3. baskı). Ankara: Pegem Akademi.

Özdemir, E. (2005). Sözlü yazılı anlatım sanatı kompozisyon. İstanbul: Remzi Kitabevi.

Özkırımlı, A. (2002). Türk Dili Dil ve Anlatım, Yaşayan Türkçe Üzerine Bir Deneme. İstanbul: İstanbul Bilgi Üniversitesi Yayınları.

Tabak, G. ve Göçer, A. (2013). 6-8. Sınıflar Türkçe Dersi Öğretim Programının Ürün ve Süreç Odaklı Yazma Yaklaşımları Çerçevesinde Değerlendirilmesi. Ahi Evran Üniversitesi Kırşehir Eğitim Fakültesi Dergisi (KEFAD) Cilt 14, Sayı 2, Sayfa 147-169.

Ülper, H. (2008). Bilişsel süreç modeline göre hazırlanan yazma öğretim programının öğrenci başarısına etkisi (Yayımlanmamış doktora tezi) Ankara Üniversitesi Sosyal Bilimler Enstitüsü, Ankara.

Yaman, E. ve Köstekçi, M. (1998). Türk dili ve kompozisyon. Ankara: Gezi Kitabevi.

Yavuz, K., Yetiş, K. ve Birinci, N. (1998). Türk dili ve kompozisyon. İstanbul: Bayrak Yayınları.

\section{Introduction}

\section{Extented Abstract}

Writing skill is a very important language skill that provides people editing their knowledge, enriching, widen their ideas and expressing conspiratorially. Being one way of expressing oneself along 
with speaking, writing is one of the most crucial communication skill that man have used for centuries. Acquiring writing skill is necessary for both meet one's basic needs, maintaining education, being successful in life, being a person who loves and understand the people, loved and understood by people and enjoy he Works written in their own mother tongue.

\section{Method}

Model

The study that carried out for evaluation of planning skills on written expression of 8 th grade students is a general survey model.

\section{Sample}

Study universe consists of 8th grade students that study in public secondary schools in Şahinbey and Şehitkamil districts in Gaziantep Province. Sample of the universe is 370 students.

\section{Data Collection Tools}

During the study, "Evaluation scale of students' opinion" and "Rubric of analysing planning skills in writing expression" were used to collect data. "Evaluation scale of students' opinion" was developed to evaluate students' opinions on planning skills in written expression. The dimensions that can be related to planning on written expression skill were presented while preparing the scale. These dimensions are 8 as "title, topic, main idea and supporting details, phrasology, ways of the improving the idea, introduction, body, and conclusion". There are 46 items as 8 in title, 6 in topic, 6 in main idea and supporting details, 2 in phraseology, 7 in ways of improving the idea, 4 in introduction, 7 in body, and 6 in conlusion. Items were ranked as " never, sometimes, always" in 3 point likert scale.

To detect the level of 8th grade students' plannig skills in written expression, "Rubric of analysing planning skills in expression" was also used as a data collection tool. Rubric consists of 7 dimensions total ( title, topic, main idea and supporting details, phrasology and ways of the improving the idea, introduction, body, conclusion ) and 5 ranking intervals (very good, good, moderate, poor, very poor ). Namely, students could get 7 points minimum, and 35 points maximum.

\section{Collecting The Data}

Writing topics were needed to make 8th graders written expression exercise. Writing topics were decided after calculating the points to 8 topics which are convenient for 8 th graders given by leading experts on this field. Topics were asked for writing a text on a topic whichever the students choose. Meanwhile, "Evaluation scale of students' opinion" was handed out and asked for filling in as necessary to identify students opinion. Data set was created after collecting the filled scale forms and texts.

\section{Analysing The Data}

The data collected in the study were evaluated with two data collection tools. Data were analysed with spss to idetify students' opinion on the practice in the context of written expression skill. In the analyse of data, descriptive statistical techniques like frequency, percentage, aritmetic mean, standard deviation were used. The answers given in the rubric were analysed to evaluate the students' skills on planning in written expression and prepared percentage and frequency.

\section{Discussion and Conclusion}

Planning skills on title dimension in rubric were identified as $13.8 \%$ very poor, $22.2 \%$ poor, $47.3 \%$ moderate, $15.7 \%$ good, and $1.1 \%$ very good. According to these data, level of nearly half of the students' plannig skills in title dimension of written expression is moderate. Level of nearly half of the students' planning skills on topic dimension is insufficient. Students' planning skills on main idea and supporting details dimension were identified as $13.5 \%$ very poor, $44.3 \%$ poor, $25.7 \%$ moderate, $13.8 \%$ good, $2.7 \%$ very good. $43.2 \%$ of students have introduction in their texts, but it is not appealing or interesting, it doesn't give general idea what it is about, and students started directly to write the texts. Students' planning skills on body dimension in the rubric were identified as $15.4 \%$ very poor, $43.2 \%$ poor, $26.8 \%$ moderate, $12.2 \%$ good, and $2.4 \%$ good. Students failed in conclusion dimension. 